\title{
Morphologic and Biochemical Variability of Tissue and Cultured Cells From Human Pheochromocytoma
}

\author{
SANDFORD JAQUES, JR.* AND MICHAEL C. TOBES \\ Division of Nuclear Medicine, Department of Internal Medicine, The University of \\ Michigan Medical Center, Ann Arbor, Michigan 48109
}

\begin{abstract}
Primary cell cultures from 18 human pheochromocytomas were maintained in culture for 10 to 12 days and characterized. The cell yields ranged from 1.0 to $60.1 \times 10^{6}$ cells/g wet weight of tissue. Cell size, as determined by histofluorescent microscopy, varied as much as seven-fold among cells derived from a given tumor and ten-fold between cells from all tumors. Cell catecholamine content, norepinephrine (NE) plus epinephrine, ranged from 0.4 to $89.5 \mathrm{nmol} /$ $10^{6}$ cells at day 5 in culture and did not correlate with catecholamine content of the tissue from which the cells were obtained. Cell catecholamine content decreased with time in culture, but this decrease could not be related to a change in cell viability, the type of media used, an inability to convert dopamine to NE, or an alteration in the uptake of ${ }^{3} \mathrm{H}-\mathrm{NE}$. Cellular uptake of $1.0 \mu \mathrm{M}$ ${ }^{3} \mathrm{H}$-NE varied as much as 230 -fold between all cell dispersions. The basal and acetylcholine stimulated release of both preloaded ${ }^{3} \mathrm{H}-\mathrm{NE}$ and the endogenous catecholamines was quite variable. There was no correlation between the release rate, either basal or stimulated, of preloaded ${ }^{3} \mathrm{H}-\mathrm{NE}$ and the endogenous catecholamines. This study represents the largest existing data base on culturing cells from these tumors and describes many of the morphologic and biochemical characteristics of this cell system.
\end{abstract}

The investigation of human pheochromocytoma has been confined primarily to in vivo studies (Manger and Gifford, 1977; Winkler and Smith, 1972), while the in vitro investigation of this adrenomedullary tumor has been confined almost exclusively to the $\mathrm{PC} 12$ rat cell line (Greene and Tischler, 1982). Since Costero et al. (1965) observed the pulsations of human pheochromocytoma cells in culture, there have been only 11 other reports using cultured cells from this tumor. The total number of tumors reported cultured to date is 25 . These studies have reported the presence of cellular catecholamines (Lamberts et al., 1984), a decline of cellular catecholamines on day 21 compared to day 0 (Tischler et al., 1984), an erratic decline of catecholamines in the culture medium (Cabana et al., 1964; Nishihira et al., 1980 ), and a loss or alteration of storage granules with time in culture (Misugi et al., 1968; Kadin and Bensch, 1971). The latter effect appeared to be partially antagonized by the presence of nerve growth factor (Pfragner et al., 1984). It has also been reported that nerve growth factor induced cell process formation (Tischler et al., 1976; Pfragner and Walser, 1980); that these cells exhibited short duration, all-or-nothing action potentials (Tischler et al., 1976); that acetylcholine and various ionophores stimulated the release of preloaded ${ }^{3} \mathrm{H}$-norepinephrine $\left({ }^{3} \mathrm{H}-\mathrm{NE}\right)$ and endogenous catecholamines as well as opioid peptides (Wilson et al., 1981); and that these cells produced neuropeptide Y (Tischler et al., 1985) as well as neurotensin and VIP-like immunoreactivity
(Tischler et al., 1984). These reports have been sporadic and have examined only one or two cell parameters, usually with cells derived from only one or two tumors.

This report presents the largest existing single data base $(n=18)$ concerned with the morphologic and biochemical characterization of cultured human pheochromocytoma cells. In addition to confirming some previously reported observations, we present the following new observations: 1) a wide range in the cell yield from a spectrum of tumors; 2) a large variation in cell size, not only between but also within tumors; 3) a lack of correlation between tissue and cellular catecholamine content; 4) the kinetics of the decrease of cellular catecholamine content with time in culture and the inability of various media and serum combinations to prevent this decrease; 5) the existence of, and variation in, the expression of an NE uptake system; and 6) the expression of different secretory patterns among the different tumor cell cultures.

\section{MATERIALS AND METHODS Materials}

Chemicals, growth factors, media, and sera were obtained from the following sources:

Received August 30, 1985; accepted March 10, 1986.

Michael C. Tobes' present address is A.T. \& T. Bell Laboratories, Holmdel, NJ 07733.

*To whom reprint requests/correspondence should be addressed. 
Collaborative Research, Inc., Waltham, MA: insulin, human transferrin, progesterone, putrescine, and selenous acid;

Grand Island Biological Co., Grand Island, NY: Minimum Essential Medium with D-valine (MEM D-VAL);

HiClone Laboratories, Logan, UT: Fetal calf serum (FCS) and plasma derived swine serum;

K.C. Biological, Lenexa, KS: Minimum Essential Medium (MEM), Dulbecco's Modified Eagle's, Ham's F12, and penicillin/streptomycin;

New England Nuclear, Boston, MA: levo-[ring-2,5,6${ }^{3} \mathrm{H}$ INE with a specific activity of 40 to $60 \mathrm{Ci} / \mathrm{mmol}^{\text {; }}$

UpJohn Diagnostics Inc., Kalamazoo, MI: Cat-A-Kit ${ }^{\mathrm{TM}}$ radioenzymatic assays;

Sigma Chemical Co, St. Louis, MO: Collagenase (Type I, 130 to 250 units/mg; Type V, 300 to 500 units/mg), DNAase (200 to $300 \mathrm{Kuntz}$ units/mg), trypsin (9,000 to 12,000 BAEE units/mg), levo-NE, levo-epinephrine (E), ascorbic acid, Percoll ${ }^{\mathrm{TM}}$, acetylcholine chloride, N-2-hydroxyethylpiperazine- $N^{\prime}$-2-ethanesulfonic acid (HEPES), and cytosine arabinoside;

Vanguard International, Neptune, NJ: Four-well Nunc Multiwell plates.

All other reagents were analytical grade or higher purity.

\section{Patients and collections of surgical specimens}

Tumor tissue was obtained under aseptic conditions from 17 patients during surgery at University Hospital (Ann Arbor, MI). One surgical specimen was obtained from a patient at Henry Ford Hospital (Detroit, MI). The ten male patients and eight female patients ranged in age from 10 to 64 years at the time of surgery. Eight of the tumors were extra-adrenal and ten were intra-adrenal. Each tumor was diagnosed as a typical pheochromocytoma from multiple histological sections by pathologists using accepted morphological criteria.

In the operating room, the intact tumor was placed in a sterile, ice cold $\mathrm{Ca}^{2+}, \mathrm{Mg}^{2+}$-free Locke's solution for transport to pathology, where the tissue was weighed and approximately one-fourth to one-half retained for histologic evaluation. The balance of the tumors $(1.5$ to $45 \mathrm{~g})$ were transported in the same ice cold, sterile solution to our laboratory. Transit time was usually less than $30 \mathrm{~min}$ from the operating room to our laboratory but was one hr when the tumor was obtained from Henry Ford Hospital.

\section{Preparation, maintenance, and characterization of cultured cells}

Tumor tissue was weighed, freed of connective tissue including capsule, and minced into pieces approximately $2 \times 2 \mathrm{~mm}$. The minced tissue was placed in a sterile beaker containing 50 to $100 \mathrm{ml}$ of $\mathrm{Ca}^{2+}, \mathrm{Mg}^{2+}$-free Locke's solution and shaken in a Dubnoff metabolic shaker at 125 oscillations per min at $37^{\circ} \mathrm{C}$ for two 20 min periods to remove red blood cells. Subsequently, the tissue was incubated with a collagenase solution in the $\mathrm{Ca}^{2+}, \mathrm{Mg}^{2+}$-free Locke's solution, for four to six digestions of 40 to $50 \mathrm{~min}$ each. The collagenase solution, approximately $0.05 \%$, consisted of two parts of Type V collagenase, adjusted to represent a constant activity of 300 units $/ \mathrm{mg}$, and one part of Type I collagenase, adjusted to represent a constant activity of 200 units $/ \mathrm{mg}$. After the first digestion with collagenase, we added ap- proximately $15 \%$ of a $0.25 \%$ trypsin solution to succeeding digestions. The digestion solutions contained 0.05 to $0.10 \mathrm{mg} / \mathrm{ml}$ of DNAase. Red blood cells and cellular debris were separated from the tumor cells by isopyncnotic centrifugation on a preformed Percoll ${ }^{\mathrm{rm}}$ gradient, which was formed using the parameters of Kilpatrick et al., (1980). Since we found that forming the gradient with the cells in situ destroyed 50 to $60 \%$ of the cells, we added the cellular digest to the top of the gradient before centrifuging them through the gradient at $450 \mathrm{~g}$ for 10 min. Freshly dispersed cells were plated at densities of 0.4 to $0.8 \times 10^{6}$ cells per well in Nunc Multiwell plates and maintained, except as noted, in MEM supplemented with $15 \%$ FCS, penicillin (100 units $/ \mathrm{ml})$, and steptomycin $(100 \mu \mathrm{g} / \mathrm{ml})$. Fibroblast growth was routinely inhibited by the addition of $10 \mu \mathrm{M}$ cytosine arbinoside. The cells were maintained at $37^{\circ} \mathrm{C}$ in a humidified incubator (Heraeus) under a $\mathrm{CO}_{2}$ :air (5:95) atmosphere and allowed to adapt to culture for four days prior to starting an experiment. After this adaptation period, the medium was changed every second or third day. At $24 \mathrm{hr}$ prior to commencing an experiment, the medium was replaced with fresh medium without cytosine arabinoside.

In order to determine whether the presence or absence of the anti-mitogen cytosine arabinoside, serum from different species, or more "nutrients" in the medium could effect cellular catecholamine levels, cells from patient 3 were maintained in four different media for 14 days. In this experiment, cells, initially plated in MEM plus FCS with cytosine arabinoside, were either maintained in that medium or changed $12 \mathrm{hr}$ later to (1) MEM plus FCS, (2) MEM D-VAL with $5 \%$ plasma derived swine serum, or (3) the $\mathrm{N}_{2}$ medium of Bottenstein and Sato (1979). The latter medium consists of a 1:1 mixture of Ham's F12 and Dulbecco's Modified Eagle's supplemented with $15 \mathrm{mM}$ HEPES, $5 \mu \mathrm{g} / \mathrm{ml}$ insulin, 100 $\mu \mathrm{g} / \mathrm{ml}$ transferrin, $20 \mathrm{nM}$ progesterone, $100 \mu \mathrm{M}$ putrescine, and $30 \mathrm{nM}$ selenium.

The cells were examined by several techniques to as. sess viability, morphologic appearance, cell size, and catecholamine content. Cell viability was greater than $90 \%$, as determined by trypan blue exclusion when the cells were plated and at the time of experiments. We did not observe significant cell lost during the experimental period. Cell loss was determined by centrifuging the "old" medium, removed during medium changes, and counting the number of cells removed at each change. Total cell loss (sum of "live" and "dead" cells) was less than $0.5 \%$ at any medium change; therefore, the maximal theoretical cell loss that could occur during a 12 day experimental period would be $2 \%$ or less. Calculations based on cell number were not corrected for this small cell loss. In the experiment with different media (Table 1), when the cell medium was changed at $12 \mathrm{hr}$, we anticipated that the cells might be loosely attached, but cell loss was less than $0.5 \%$. Since there was no significant cell loss, cell viability, at the time of experimentation, was determined by adding trypan blue directly to the culture wells. General cell morphology was visualized and photographed using an inverted Nikon phase-contrast microscope. Histofluorescent (De La Torre and Surgeon, 1976) photomicroscopy (Leitz Ortholane$355 \mathrm{~nm}$ excitation and $455 \mathrm{~nm}$ emission) was used to assess the purity of the cell preparation and to permit 
an accurate measurement of pheochromocytoma cell size. Using photomicrographs, 25 to 50 fluorescent, catecholamine containing cells per dispersion were measured. Perchloric acid cell extacts were routinely assayed for $\mathrm{E}$ and $\mathrm{NE}$ using the differential fluorometric assay technique of Anton and Sayre (1962). In some experiments, cell dopamine, in addition to $\mathrm{E}$ and $\mathrm{NE}$, content was determined using the Cat-A-Kit ${ }^{\text {Th }}$, a modification of the radioenzymatic technique of Passon and Peuler (1973). Prior to mincing the tissue for a cell dispersion, several 100 to $200 \mathrm{mg}$ samples of the tumor were set aside for assay of tissue catecholamine content; the tissue was homogenized with nine volumes of $0.4 \mathrm{~N}$ perchloric acid, and the $20,000 \mathrm{~g}$ supernatant was assayed by the differential fluorometric or radioenzymatic assay. Catecholamine content was expressed as nmol/10 6 cells and $\mu \mathrm{mol} / \mathrm{g}$ wet weight tissue.

\section{Incubation conditions for ${ }^{3} \mathrm{H}$-NE uptake}

The uptake protocol and conditions have been described previously (Jaques et al., 1984; Tobes et al., 1985). Briefly, 4 to 12 days post-dispersion, the tissue culture plates were placed in a $37^{\circ} \mathrm{C}$ water bath or an ice water bath $\left(0.5\right.$ to $\left.1.5^{\circ} \mathrm{C}\right)$. Fifteen min prior to commencing the uptake study, the MEM culture medium was removed and the cells were preincubated, at either temperature, with $0.5 \mathrm{ml}$ HEPES buffered Krebs Ringer Glucose $(\mathrm{H}$ KRG), containing $1 \mathrm{mM}$ ascorbic acid adjusted to a final $\mathrm{pH}$ of 7.35. Following the pre-incubation, the cells in each well were incubated with $0.30 \mathrm{ml} \mathrm{H}$-KRG containing $1.0 \mu \mathrm{M}{ }^{3} \mathrm{H}-\mathrm{NE}$. At the end of the incubation period, the plates were placed on ice, the ${ }^{3} \mathrm{H}-\mathrm{NE}$ containing $\mathrm{H}$ KRG was removed, and the cells were washed twice. The ${ }^{3} \mathrm{H}$-NE taken up by the cells was extracted with trichloroacetic acid, which, following the addition of scintillant, was counted in a Beckman LS 7500 liquid scintillation system for $10 \mathrm{~min}$ or to a 2 Sigma error of $0.5 \%$.

The $37^{\circ} \mathrm{C}$ incubations were done in quadruplicate, while the $0^{\circ} \mathrm{C}$ incubations were done in duplicate. The total uptake was determined by correcting the uptake at $37^{\circ} \mathrm{C}$ for nonspecific uptake at $0^{\circ} \mathrm{C}$. The uptake of 1.0 $\mu \mathrm{M} \mathrm{NE}$ at $37^{\circ} \mathrm{C}$ was linear for $20 \mathrm{~min}$ or more in all experiments. Uptake was standardized as pmol/10 6 cells/ $10 \mathrm{~min}$ because cell numbers, as well as the incubation time with different cell preparations, varied. Each experiment was repeated at least once, usually 3 to 5 days after the initial experiment; the results of single experiments are presented. Each data point represents the mean of quadruplicate values \pm the standard deviation.

In order to determine whether fibroblast "contamination" could significantly effect the estimation of ${ }^{3} \mathrm{H}-\mathrm{NE}$ uptake by pheochromocytoma cells, a pure preparation of fibroblasts isolated from a dispersion of the tumor from patient 14 was plated in the Nunc Multiwell plates. Five days later, when the cell monolayer was confluent, the uptake of ${ }^{3} \mathrm{H}-\mathrm{NE}$ by these fibroblast cells was determined as described above but was expressed as pmol/ well, since the confluent culture yielded only 67,000 cells/well.

Release of ${ }^{3} \mathrm{H}-\mathrm{NE}$ and endogenous catecholamines

At 4 to 12 days post-dispersion, cells were preloaded with ${ }^{3} \mathrm{H}$-NE by incubating the cells with $0.30 \mathrm{ml} \mathrm{H}-\mathrm{KRG}$ containing $1.0 \mu \mathrm{M}{ }^{3} \mathrm{H}$-NE for a 30 - to 45 - min period, during which uptake was linear. At the end of this period, the cells were washed twice with one $\mathrm{ml}$ of HEPES buffered-Locke's solution and then washed further by incubating for two 10-min periods in fresh Locke's solution (Kilpatrick et al., 1980). Following the removal of the last wash, the cells were incubated for 10 min with $0.64 \mathrm{ml}$ of Lock's solution, either in the presence (stimulated release) or absence (basal release) of $100 \mu \mathrm{M}$ acetylcholamine. At the end of this period, both cell and media content of ${ }^{3} \mathrm{H}-\mathrm{NE}$ were determined. The medium was transferred directly to a scintillation vial, scintillant added, and the mixture counted. The cell radioactivity was extracted with trichloroacetic acid and counted as described above. Release is expressed as a percentage of the total radioactivity within the cell system, i.e., radioactivity recovered in the medium divided by the sum of radioactivity in the medium and cells. The results of a single experiment are presented; each data point represents the mean \pm the standard deviation. All steps of the experimental protocol, preloading of ${ }^{3} \mathrm{H}-\mathrm{NE}$, washes, and release were carried out at $37^{\circ} \mathrm{C}$.

The release of endogenous catecholamines was determined following the same experimental protocol. However, quantitation of cell and medium catecholamines using either of the two catecholamine assays required that the media be made $0.05 \mathrm{~N}$ perchloric acid. Therefore, $0.013 \mathrm{ml}$ of $2.5 \mathrm{~N}$ perchloric acid was added to the $0.64 \mathrm{ml}$ of the stimulus or basal release solution removed from the incubation well. Cell catecholamines were extracted with $0.5 \mathrm{ml}$ of $0.4 \mathrm{~N}$ perchloric acid in Locke's solution, which was then diluted to $0.05 \mathrm{~N}$ prior to assay. Standard curves for the fluorometric assay were generated using authentic $\mathrm{E}$ and NE. Cell and medium catecholamine content was calculated as nmol/ $10^{6}$ cells. Release was expressed as a percentage of the total $\mathrm{E}$ and $\mathrm{NE}$ in the medium divided by the total within the cell system. Differences between means were determined using Student's t-test.

\section{RESULTS \\ Cell yield, cell size, and cell morphology}

The cell yield from the 18 pheochromocytomas was quite variable; $73 \%$ of the tumors yielded 1.0 to $13.8 \times$ $10^{6}$ cells/g wet weight of tissue, while the balance yielded 19.5 to $61.6 \times 10^{6}$ cells $/ g$ wet weight of tissue. There was no relationship between the cell yield and the anatomical location of the tumor.

When first plated, the cells appeared as round, individ ual, phase-dark, epithelial-like cells (Fig. 1A) when visualized with phase contrast microscopy. Cell size, both within and between tumors, varied significantly. A fivefold variation in cell diameter, from the tumor dispersion of patient 1 , is observed within a single microscopic field in Fig. 1B ( $\times 375$ ). Figure 2 illustrates the variabil ity, and general asymmetric distribution, of cell size (diameter) within six tumors. The cell size distribution in tumors from patients 1 and 11 (Fig. 2A and 2E) approximate a normal distribution, although clearly the most common cell sizes were different: 20 to $30 \mu \mathrm{m}$ for patient 1 , but only 10 to $15 \mu \mathrm{m}$ for patient 11 . In contrast, the distribution of cell size in tumors from patients 2,8 , and 15 (Fig. 2B, 2D, and $2 \mathrm{~F}$ respectively) was skewed toward the smaller tumor cells (5 to $10 \mu \mathrm{m}$ in diameter for patient 8 , and 10 to $15 \mu \mathrm{m}$ in diameter for patients 2 and 15). Tumor cells from patient 5 (Fig. 2C) exhibited a 

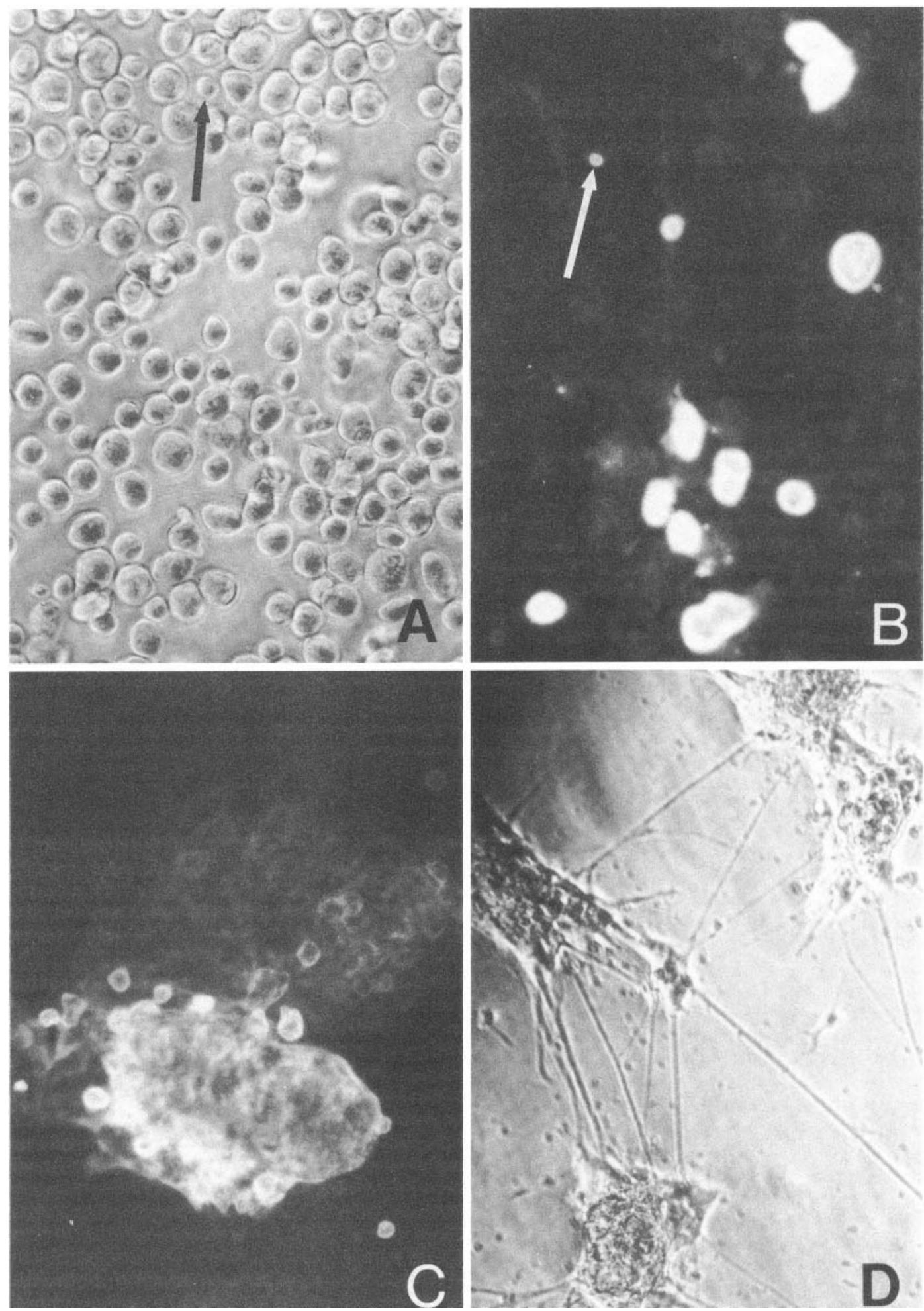

Fig. 1. Photomicrographs of human pheochromocytoma cells in culture. A: phase contrast micrograph of cells from patient 11 at the time of plating $(\times 725)$; the arrow indicates a cell approximately $4.8 \mu \mathrm{m}$ in diameter. B: glyoxylic acid treatment of cells from patient 1, illustrating a five-fold range in size of fluorescent, catecholamine containing

cells at day $10(\times 375)$; the arrow indicates a cell approximately $5.0 \mu \mathrm{m}$ in diameter. $\mathrm{C}$ : clumping or colony formation of fluorescent catecholamine containing cells of patient 11 at day $5(\times 390)$. D: phase contrast micrograph of spontaneously occurring, axon-like processes of cells from patient 11 at day $60(\times 150)$. 

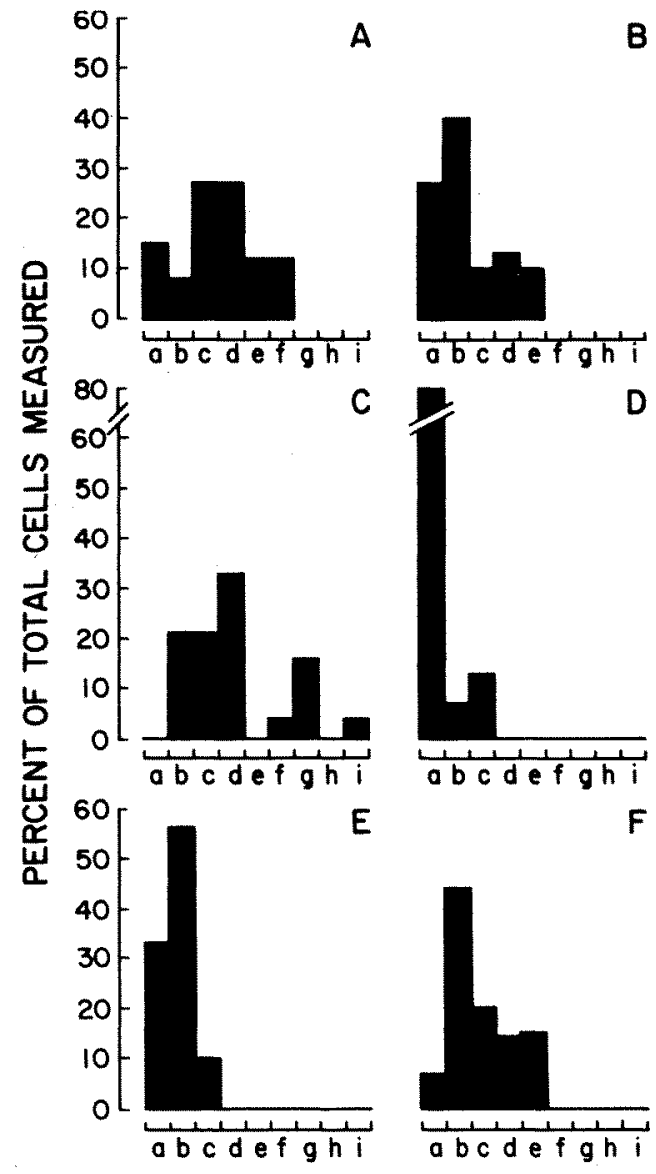

Fig. 2. Frequency, in percent, of fluorescent, catecholamine-containing cells grouped by $5 \mu \mathrm{m}$ intervals in cell diameter. The small letters on the abscissa represent $5 \mu \mathrm{m}$ divisions of cell size: $\mathrm{a}=5$ to $9, \mathrm{~b}=10$ to $14, \mathrm{c}=15$ to $19, \mathrm{~d}=20$ to $24, \mathrm{e}=25$ to $29, \mathrm{f}=30$ to $34, \mathrm{~g}=35$ to $39, \mathrm{~h}=40$ to 45 , and $\mathrm{i}=46$ to 50 . A: cells from patient $1 ; \mathrm{B}$ : cells from patient 2; C: cells from patient 5 ; D: cells from patient 8 ; E: cells from patient 11; and F: cells from patient 15.

very non-uniform size distribution and the largest range in cell size (from 10.7 to $47.1 \mu \mathrm{m}$ in diameter). Examples of the small cells, approximately $5 \mu \mathrm{m}$ in diameter, as visualized by phase-contrast and histofluorescent microscopy, are indicated with arrows in Fig. 1A and 1B.

The pheochromocytoma cells became firmly attached after three to four days in culture. The round cells frequently coalesced into clumps or groups (Fig. 1C) and flattened somewhat as the cell membranes become less distinct. When pheochromocytoma cells in maintenance and proliferation experiments were maintained in culture for extended periods, they often assumed a polygonal or stellate shape. When pheochromocytoma cells were maintained in culture for 28 days or more, 9 of 17 spontaneously developed long axon-like processes (Fig. 1D). This occurred as early as 5 days after plating and was delayed for as long as 65 days. Within these nine long-term experiments, the median time to the appearance of processes was 20 days. In these experiments, the appearance of a polygonal or stellate cell conformation, which often preceded the appearance of the axon-like processes, usually occurred at lower plating densities

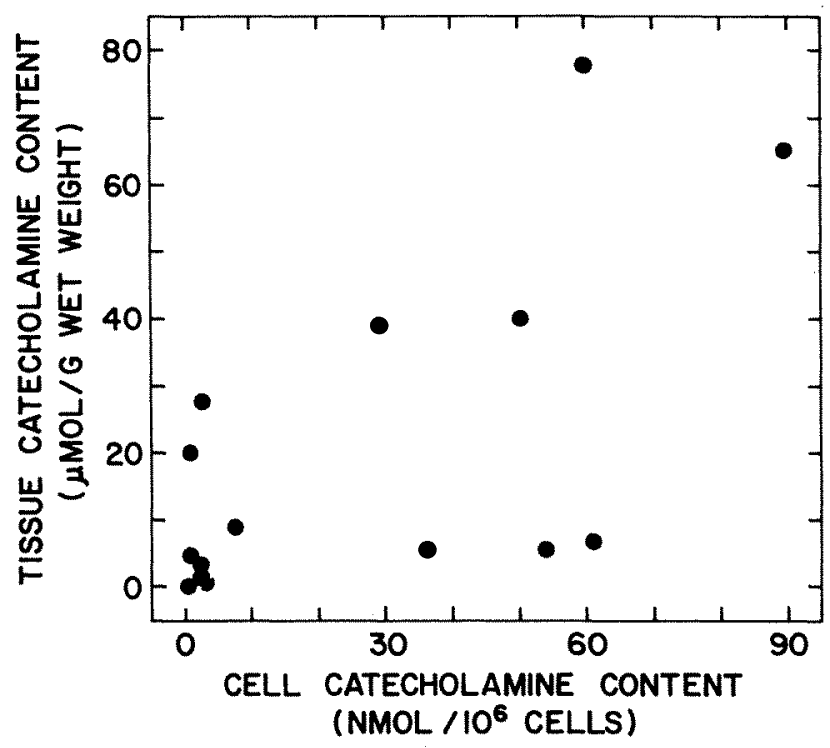

Fig. 3. Relationship of pheochromocytoma tissue catecholamine (E plus NE) content ( $\mu \mathrm{mol} / \mathrm{g}$ wet weight) to cell catecholamine (E plus NE) content ( $\mathrm{nmol} / 10^{6}$ cells), at day 5 of culture $(\mathrm{N}=15$ ).

and/or after passaging the cells several times. However, in the "short term" studies reported here, the cells maintained a spherical shape.

\section{Tissue and cell catecholamine content}

Both tissue and cell catecholamine content, which was predominantly $\mathrm{E}$ and $\mathrm{NE}$, varied widely from tumor to tumor. The sum of tissue $\mathrm{E}$ plus NE content varied from 0.17 to $77.3 \mu \mathrm{mol} / \mathrm{g}$ wet weight. $\mathrm{NE}$ was the principle catecholamine in most tissues and cell extracts. Nine of the ten intra-adrenal pheochromocytomas contained both $\mathrm{E}$ and NE, while one contained only NE. Seven of the eight extraadrenal tumors contained only NE, while one had a small amount of E, approximately $1 \%$ of the sum. The sum of cell $\mathrm{E}$ and NE content varied 224-fold, from 0.4 to $89.5 \mathrm{nmol} / 10^{6}$ cells at day 5 in culture. The sum of tissue $\mathrm{E}$ and $\mathrm{NE}$ varied 326 -fold, from 0.2 to 65.2 $\mu \mathrm{mol} / \mathrm{g}$ wet weight. However, there was a low correlation $(r=0.636)$ between tissue and cell content of these catecholamines (Fig. 3); the correlation was not improved by the inclusion of cellular dopamine content or when only the NE content of cell and tissue was compared.

The cellular content of catecholamines in cultured tumor cells decreased with time in all cultures. With one exception (Table 1, patient 3), the decrease in cellular NE content was linear, as illustrated in Figure $4 \mathrm{~A}$ and $4 \mathrm{~B}$. In cells capable of synthesizing $\mathrm{E}$, this catecholamine, without exception, declined linearly with time in culture (Fig. 4B); the inability to synthesize $\mathrm{E}$ did not change with time in culture (Fig. 4A). Since the decline of cellular $\mathrm{E}$ and $\mathrm{NE}$ might have been due to an inability of the cells to hydroxylate dopamine, these levels were measured over the duration of two cultures. The cellular dopamine levels were stable, averaging $6.0 \pm 0.9 \mathrm{nmol} /$ $10^{6}$ cells over the 12 -day culture period of cells from patient 3 and $4.3 \pm 1.1 \mathrm{nmol} / 10^{6}$ cells over the 8-day 


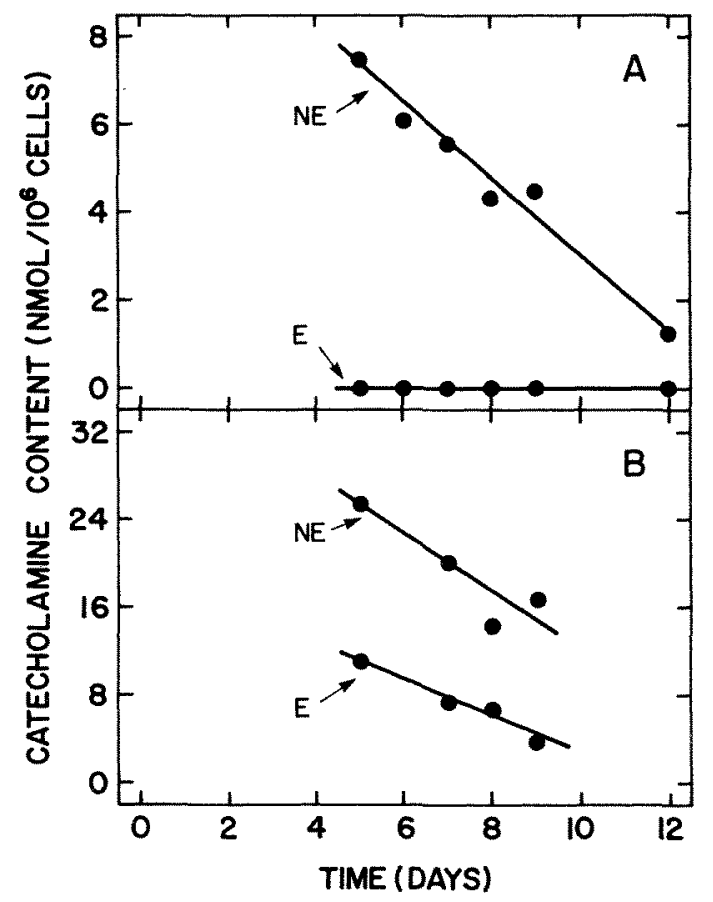

Fig. 4. Cellular catecholamine ( $\mathrm{E}$ and $\mathrm{NE}$ ) content, expressed as nmol/ $10^{\mathrm{g}}$ cells, of cultured pheochomocytoma cells, as a function of time (days) in culture. A: cells derived from an intra-adrenal tumor from patient 18; NE and $\mathrm{E}$ cell content. B: cells derived from an intraadrenal tumor from patient $11 ; \mathrm{NE}$ and $\mathrm{E}$ cell content.

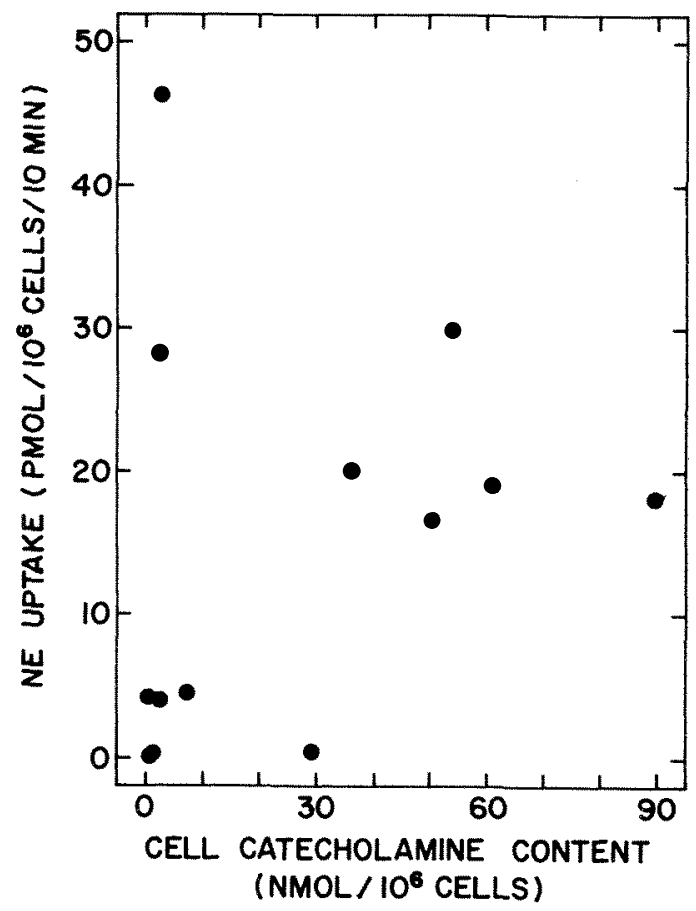

Fig. 5. Relationship of the uptake of $1.0 \mu \mathrm{M}{ }^{3} \mathrm{H}-\mathrm{NE}$ (pmol/10 $10^{6}$ cells $/ 10$ min) to cellular catecholamine content ( $\mathrm{nmol} / 10^{6}$ cells) at day 5 of culture, as determined in cultured cells from 13 pheochromocytomas.

TABLE 1. Catecholamine content ( $E$ and NE) of pheochromocytoma cells from patient 3 on days 1, 3, 7, and 13, post-plating, when maintained in one of four different media ${ }^{1}$

\begin{tabular}{|c|c|c|c|c|c|c|c|c|c|}
\hline \multirow[b]{3}{*}{ Medium } & \multicolumn{8}{|c|}{ Cell catecholamines (nmol/10 $10^{6}$ cells) } & \multirow{3}{*}{$\begin{array}{l}\text { Percentage loss } \\
\text { of catecholamines } \\
\text { by Day } 13^{4} \\
(\%)\end{array}$} \\
\hline & \multicolumn{2}{|c|}{ Day 1} & \multicolumn{2}{|c|}{ Day 3} & \multicolumn{2}{|c|}{ Day 7} & \multicolumn{2}{|c|}{ Day 13} & \\
\hline & $\mathrm{E}$ & $\mathrm{NE}$ & $E$ & $\mathrm{NE}$ & $E$ & NE & $E$ & $\mathrm{NE}$ & \\
\hline $\begin{array}{l}\text { MEM }+15 \% \text { FCS }+ \\
\text { cytosine arabinoside }\end{array}$ & 3.6 & 98.8 & 1.7 & 67.4 & 0.36 & 27.6 & 0.0 & $13.0^{3}$ & 87.3 \\
\hline MEM $+15 \%$ FCS & & & - & - & 0.4 & 34.6 & 0.1 & 11.2 & 89.0 \\
\hline $\mathrm{N}_{2}$ Medium $^{2}$ & & & 1.5 & 48.1 & 0.5 & 22.2 & 0.0 & 12.3 & 88.0 \\
\hline $\begin{array}{l}\text { MEM D-VAL }+ \\
5 \% \text { plasma-derived } \\
\text { swine serum }\end{array}$ & & & 1.6 & 90.2 & 0.7 & 33.7 & 0.0 & 20.9 & 79.6 \\
\hline
\end{tabular}

${ }^{1}$ Cells were plated at $0.69 \times 10^{6}$ cells/well in MEM $+15 \% \mathrm{FCS}+$ cytosine arabinoside. Twelve hr later, this medium was carefully replaced with fresh MEM + FCS + cytosine arabinoside or one of the other media. No cells $(<0.05 \%)$ were found in the medium that was removed at $12 \mathrm{hr}$ or at subsequent medium changes; see Materials and Methods. The reported catecholamine values are the mean of two determinations.

${ }^{2}$ Defined medium of Bottenstein and Sato (1979). See Materials and Methods.

${ }^{3}$ Day 14 value.

${ }^{4} \mathrm{E}$ plus NE: (Day $1-$ Day 13)/Day $1 \times 100$.

culture period of cells from patient 11 . In both cultures, dopamine was a relatively minor component of total catecholamine content, representing only $14 \%$ and $5 \%$, respectively, of the total cellular catecholamines at day 5.

In the cells from patient 3 (Table 1), the decline in cellular $\mathrm{E}$ and $\mathrm{NE}$ was not prevented by the presence or absence of cytosine arabinoside, or replacement of FCS with the hormonally defined $\mathrm{N}_{2}$ medium. The decrease in cellular catecholamines was least when the FCS was replaced with plasma-derived swine serum. In none of these cultures was the decline in cellular catechol- amines related to a decline in cell viability, which was greater than $90 \%$ by trypan blue exclusion at all times.

\section{Uptake and release of ${ }^{3} \mathrm{H}-\mathrm{NE}-$ relationship to endogenous $\mathbf{E}$ and $\mathrm{NE}$}

Uptake of $1.0 \mu \mathrm{M}{ }^{3} \mathrm{H}-\mathrm{NE}$ varied more than 230 -fold $\left(0.2\right.$ to $46.2 \mathrm{pmol} / 10^{6}$ cells $\left./ 10 \mathrm{~min}\right)$ between 16 different cell preparations. There was a poor correlation between ${ }^{3} \mathrm{H}-\mathrm{NE}$ uptake and the cellular content of $\mathrm{E}$ plus $\mathrm{NE}$ (Fig. 5), and E or NE alone ( $r \leqslant 0.243$ ). Additionally, no correlation was found between ${ }^{3} \mathrm{H}-\mathrm{NE}$ uptake and the "most common" cell size (data not shown). Although 
TABLE 2. Basal and acetylcholine (ACh) stimulated release of preloaded ${ }^{3} \mathrm{H}-\mathrm{NE}$ and endogenous catecholamines from pheochromocytoma cells ${ }^{1}$

\begin{tabular}{ccccc}
\hline Patient & $\pm \mathrm{ACh}$ & ${ }^{3}{\mathrm{H}-N E^{2}}^{2}$ & E plus NE & Cell age \\
\hline 1 & + & $14.4 \pm 1.2^{*}(3)$ & $27.9(2)$ & 5 \\
& - & $8.2 \pm 1.3(3)$ & $22.4(2)$ & \\
9 & + & $20.6 \pm 0.5^{*}(3)$ & $8.6 \pm 1.2^{*}(4)$ & 5 \\
& - & $3.3 \pm 0.5^{*}(3)$ & $3.1 \pm 0.5(4)$ & \\
13 & + & $11.0 \pm 1.8(4)$ & $20.3 \pm 2.5^{*}(3)$ & 8 \\
& - & $13.1 \pm 2.0(4)$ & $12.2 \pm 1.5(3)$ & \\
18 & + & $43.3 \pm 2.9^{*}(4)$ & $11.5 \pm 2.5^{*}(4)$ & 13 \\
& - & $36.7 \pm 1.2(4)$ & $1.7 \pm 0.4(4)$ & \\
\hline
\end{tabular}

${ }^{1}$ Release is expressed as a percentage of total $\mathrm{E}$ and $\mathrm{NE}$ in the medium divided by the total within the cell system. The cells were treated with buffer plus $100 \mu \mathrm{M} \mathrm{ACh}(+)$ or buffer alone $(-)$ for $10 \mathrm{~min}$. The numbers in parentheses indicate the number of wells per treatment group.

${ }^{2}$ Cells were preloaded with $1.0 \mu \mathrm{M}^{3} \mathrm{H}$-NE for 30 to $45 \mathrm{~min}$, washed twice, then washed further with two 10 -min incubation periods prior to the addition of buffer plus ACh or buffer alone.

${ }^{3}$ Cells assayed for the release of endogenous catecholamines ( $\mathrm{E}$ plus NE) were handled in parallel with those assayed for release of preloaded ${ }^{3}$ H-NE.

${ }^{4}$ Number of days in which the cells were maintained in culture prior to performing the release experiment. Release of preloaded ${ }^{3} \mathrm{H}-\mathrm{NE}$ and the endogenous catecholamines was determined on the same day with the same solutions.

Statistically different than basal release; $p \leqslant 0.05$

cellular catecholamine content declined with time in culture, the uptake of ${ }^{3} \mathrm{H}-\mathrm{NE}$ (pmol/10 ${ }^{6}$ cells $/ 10 \mathrm{~min}$ ) remained stable or increased. For example, uptake of $1.0 \mu \mathrm{M}{ }^{3} \mathrm{H}-\mathrm{NE}$ by the cells from patient 18 remained stable $(3.3 \pm 0.9$ on day 5 of culture and $4.6 \pm 0.4$ on day 10), while cellular catecholamine levels declined $60 \%$ over this same period (Fig. 4A). Uptake of ${ }^{3} \mathrm{H}-\mathrm{NE}$ by the cells from patient 11 increased nearly $50 \%$ between days 5 and 9 , while cellular catecholamine levels declined $33 \%$ over this same time period (Fig. 4B). The contribution of contaminating fibroblasts to the determination of ${ }^{3} \mathrm{H}-\mathrm{NE}$ uptake by pheochromocytoma cells was assessed by growing isolated fibroblasts from patient 14 to confluence; under these conditions, the up take of ${ }^{3} \mathrm{H}-\mathrm{NE}$ by the fibroblasts was $0.07 \mathrm{pmol} / \mathrm{well} / 10$ min, which was significantly less than the uptake of ${ }^{3} \mathrm{H}$ $\mathrm{NE}$ by all but one tumor cell culture.

Release, either basal or acetylcholine stimulated, of the endogenous catecholamines and preloaded ${ }^{3} \mathrm{H}-\mathrm{NE}$ was different between the different cell cultures. The basal and acetylcholine stimulated release of preloaded ${ }^{3} \mathrm{H}$-NE and endogenous catecholamines from the cells of four tumors is shown in Table 2. Within these four cell cultures, the basal release of preloaded ${ }^{3} \mathrm{H}-\mathrm{NE}$ varied more than ten-fold ( 3.3 to $36.7 \%)$; in fact, the basal release of preloaded ${ }^{3} \mathrm{H}-\mathrm{NE}$ from the cells of patient 18 was greater than the stimulated release of preloaded ${ }^{3} \mathrm{H}-\mathrm{NE}$ from the cells of the other three tumors. The basal release of endogenous $\mathrm{E}$ and $\mathrm{NE}$ varied 14-fold, from 1.6 to $22.4 \%$. As with the release of preloaded ${ }^{3} \mathrm{H}$ $\mathrm{NE}$, the basal release of the endogenous catecholamines from the cells of one tumor (patient 1) was greater than the acetylcholine stimulated release of endogenous catecholamines from the cells of the other three tumors. Acetylcholine increased the release of preloaded ${ }^{3} \mathrm{H}-\mathrm{NE}$ more than six-fold over the basal rate from the cells of patient 9 , but it had no stimulatory effect upon the release of preloaded ${ }^{3} \mathrm{H}-\mathrm{NE}$ from the cells of patient 13 . The acetylcholine stimulated release of endogenous catecholamines also showed a gradation in release; nearly a seven-fold increase from the cells of patient 18 to a very minimal response from the cells of patient 1 . There was no consistent parallel between the release, whether basal or acetylcholine stimulated, of preloaded ${ }^{3} \mathrm{H}-\mathrm{NE}$ and the endogenous catecholamines.

\section{DISCUSSION}

During the past 20 years, only a handful of investigators have cultured cells from a limited number of human pheochromocytomas. Of the 12 investigations, 9 studied cells from only one or two of these tumors. We have cultured cells from 18 pheochromocytomas and provide new observations and insights on: 1) tumor cell yield, 2) the variation of cell size within and between these tumors, 3) cell morphology in culture, 4) the lack of correlation between cell and tissue catecholamine content, 5) the kinetics of the decrease of cellular catecholamine with time in culture and the inability of different media/ serum combinations to prevent this decrease, 6) the existence and variability in the expression of an NE uptake system, and 7) the variability in basal and acetylcholine stimulated release of endogenous catecholamines and preloaded ${ }^{3} \mathrm{H}-\mathrm{NE}$.

The cell yield from the 18 pheochromocytomas varied more than 70-fold, although it appeared that there were "high" and "low" yield types of tumors. This variability probably reflects the heterogeneity of these tumors, since, in our hands, dispersions of the more homogeneous bovine adrenomedullary tissue exhibit only a twofold variation in cell yield (Jaques and Tobes, unpublished observation).

Within a given tumor, a diversity of cell size was observed (Fig. 2). We used histofluorescent microscopy to identify the catecholamine-containing pheochromocytoma cells and observed a three- to seven-fold variation in cell diameter within tumors. The maximal variation in cell diameter between all tumors was ten-fold: 4.8 to $47.1 \mu \mathrm{m}$. This represents a far greater variation than reported by Tischler et al. (1976), which described pheochromocytoma cells as "...15 to $20 \mu \mathrm{m}$ in diameter." We found that the "most common" size of cells within a tumor could occur anywhere within the range of cell size for that tumor, i.e., cell size within a tumor seldom followed a Gaussian distribution. In nearly all cell dispersions, five of the six illustrated in Fig. 2, we observed the occurrence of a population of "small" cells, 5 to $6 \mu \mathrm{m}$ 
in diameter, which is the size of the catecholaminecontaining, small, intensely fluorescent (SIF) cells located in sympathetic ganglia (Eranko, 1976; Kanerva and Hervonen, 1976). The significance of the variation of cell size and the presence of a population of "small" cells within these tumors is unknown; the "most common" cell size did not correlate with any of the biochemical characteristics that were examined.

In contrast to other investigators (Pfragner and Walser, 1980; Tischler et al., 1976, 1984; Nishihira et al., 1980 ), we observed spherical cells more frequently than a polygonal or stellate conformation. Clumping or "colony" formation of the round, as well as of the stellate cells, occurred frequently. Transformation of the round cells to a polygonal or stellate shape, which was not common, usually occurred after 12 to 30 days in culture and usually preceded the development of axon-like processes. Processes developed in 9 to 17 long term cultures; this occurred as early as day 5 and was delayed for as long as 65 days. We were not able to determine, from a retrospective analysis of the data, whether or not the appearance of the axon-like processes reflected differences in the cell density, number of passages, an interaction with the different substrates (plastic, collagen, or polylysine), nerve growth factor synthesis by fibroblasts (Young et al., 1975), or of the morphologic potential of the cells themselves.

Although differences in pheochromocytoma tissue catecholamine content have been reported (Winkler and Smith, 1968; Blaschko et al., 1968; Wrzolkowa et al., 1975; Feldman et al., 1979; Feldman, 1981) and catecholamine values from five tumors at day 0 were reported (Tischler et al., 1984), tissue and cell catecholamine levels have not previously been evaluated in parallel. We found that both tissue and cell catecholamine content ( $\mathrm{E}$ plus NE) varied widely, 326- and 224-fold, respectively, and that there was a poor correlation between cell and tissue content. This lack of correlation was not improved by comparing only $\mathbf{E}$ or only NE. Possible explanations for this poor correlation are: 1) the heterogeneity of the tissue relative to the "homogeneity" of the cell preparation; 2) different rates, between tumors, of decline of cellular catecholamines in culture; or 3 ) changes in the capacity of the cells to synthesize and /or store catecholamines when they are maintained in culture. Dopamine appeared to be a minor component of the total catecholamine content within these cells, and its inclusion in cell catecholamine content did not improve the lack of correlation between tissue and cellular catecholamine content.

The determination of the kinetics of the decline in cellular $\mathrm{E}$ and $\mathrm{NE}$ with time in culture confirms and expands the report of Tischler et al. (1984), which described an 87 to $99 \%$ decrease in cellular catecholamine content, per culture dish, at day 21 relative to day 0 . We explored several possible explanations for the decrease in cellular catecholamines with time in culture. We did not observe a decrease in cell number or viability with time in culture. Tischler et al. (1984) suggested that these factors were partially responsible for the decrease in cellular catecholamines that they observed. It seems likely that the cell loss described by Tischler et al. (1984) is a function of cell density and/or cell-to-cell interaction. Our cells were plated at a density of 200,000 to 400,000 cells per $\mathrm{cm}^{2}$. Their cells were plated in petri dishes of unstated size. If it is assumed that they used $35 \mathrm{~mm}$ petri dishes, the maximal cell density in any of their cultures would have been 18,000 cells per $\mathrm{cm}^{2}$, a cell density, minimally, 10 - to 20 -fold less than in our experiments. We have also found that we "lose" cells at these low plating densities.

The stable uptake of ${ }^{3} \mathrm{H}-\mathrm{NE}$ over time in culture and the low and relatively stable levels of dopamine with time in culture, which Tischler et al. (1984) also observed, suggests that the time-dependent decrease in cellular $\mathrm{E}$ and $\mathrm{NE}$ content was not related either to an inability of the cells to take up NE or to convert dopamine to NE. The latter observation is in contrast to the findings in adrenomedullary cell systems when cellular dopamine was found to increase as $\mathrm{E}$ and NE declined (Unsicker, 1983). We also considered the possibility that the decline of cellular catecholamines might be due to: 1) the absence of serum or medium factors required for catecholamine synthesis and/or storage; 2) inhibitory factors that might be present in the serums; or 3) cytosine arabinoside, which might inhibit this cell function (Table 1). The loss of cellular E and NE when the cells were maintained in MEM plus FCS with or without cytosine arabinoside was similar, indicating that this anti-mitogen had no effect on catecholamine content. The presence of more amino acids, nucleic acids, vitamins, and co-enzymes, or the lack of serum factors in the neuronal specific $\mathrm{N}_{2}$ medium (Bottenstein and Sato, 1979; Bottenstein, 1983) did not affect the rate of catecholamine decline relative to the two MEM plus FCS media. The loss of cellular $\mathrm{E}$ and NE was least when the cells were maintained in MEM D-VAL with plasmaderived swine serum, suggesting a species effect of the serum or an inhibitory effect of MEM D-VAL upon fibroblast growth (Gilbert and Migeon, 1975; Dickinson and Slakey, 1982). However, all of these differences were small and do not suggest a causative association. On the basis of these experiments, it appears that the requirements for maintaining cellular catecholamine levels in culture are quite different than those for maintaining other cell functions such as a stable rate of ${ }^{3} \mathrm{H}-\mathrm{NE}$ uptake, the ability to exclude trypan blue, or the ability to synthesize axon-like processes.

Although Anderson et al. (1973) described the in vivo uptake of ${ }^{14} \mathrm{C}$-dopamine by a presumed catecholamine uptake mechanism in human pheocromocytoma, we provide the first direct evidence of an NE uptake mechanism in this tumor. The expression of this mechanism varied more than 230 -fold when uptake was determined at a concentration of $1.0 \mu \mathrm{M}^{3} \mathrm{H}-\mathrm{NE}$ (Fig. 5). The uptake values at this concentration do not reflect variations in the amount of endogenous cellular NE concurrently secreted into the medium; therefore, the "true" concentration of $\mathrm{NE}$ in the medium during the assay may be greater than $1.0 \mu \mathrm{M}$. Thus, an underestimation of "real" uptake would be most pronounced in those cells with "high" basal secretion rates. However, it does not appear that basal secretion significantly influenced uptake, since an inverse correlation between high basal secretion and low measured uptake of ${ }^{3} \mathrm{H}-\mathrm{NE}$ was not observed (data not shown). We were unable to correlate the 230 -fold variation in the rate of ${ }^{3} \mathrm{H}$-NE uptake with variations in any of the other biochemical parameters 
examined. The physiologic function, if any, or NE uptake in adrenomedullary and pheochromocytoma cells is not known.

The uptake of ${ }^{3} \mathrm{H}-\mathrm{NE}$ by fibroblasts was very low and a minor source of error in all experiments except one. If fibroblasts had grown to total confluency (a process routinely inhibited by the presence of cytosine arabinoside), fibroblast uptake of ${ }^{3} \mathrm{H}-\mathrm{NE}$ could have contributed to an over-estimation of uptake by tumor cells by 0.1 to $1.8 \%$ in 17 of 18 cell preparations. The determination of ${ }^{3} \mathrm{H}$ $\mathrm{NE}$ uptake by the tumor cells of patient $14\left(0.2 \mathrm{pmol} / 10^{6}\right.$ cells $/ 10 \mathrm{~min}$ ) would be over-estimated by $54 \%$ if fibroblasts had grown to confluency, i.e., "real" uptake would be 0.2 minus $0.07 \mathrm{pmol} / 10^{6}$ cells $/ 10 \mathrm{~min}$.

Our studies demonstrate the expression of different secretory patterns in human pheochromocytoma cells. Normal adrenomedullary cells have a low rate of basal release, typically 3 or $4 \%$. In these cells, acetylcholine, or its nicotinic agonists, normally stimulate release three- to seven-fold above basal levels (Hochman and Perlman, 1976; Lang and Perlman, 1979; Fenwick et al., 1978; Kilpatrick et al., 1980), and the endogenous catecholamines and preloaded ${ }^{3} \mathrm{H}-\mathrm{NE}$ are released in parallel (Kilpatrick et al., 1980; Trifaro and Lee, 1980). Although our release studies suggest that some similarities to release in normal adrenomedullary cells remain, release from the human pheochromocytoma cells was always different than the release from normal adrenomedullary cells with respect to at least one of the following criteria: 1) elevated basal release, 2) lack of response to acetylcholine, or 3) nonparallel release of endogenous catecholamines and preloaded ${ }^{3} \mathrm{H}-\mathrm{NE}$ (Table 2). The basal release of endogenous catecholamines from the cells of patients $9(3.3 \%)$ and $18(1.7 \%)$ was similar to that of "normal" adrenomedullary cells. In contrast, the basal release of endogenous catecholamines in the cells from patients 1 and 13 ( 22.4 and $12.2 \%$, respectively) was as high or higher than the acetylcholine-stimulated release in the other tumor cells or in normal adrenomedullary cells (Hochman and Perlman, 1976; Lang and Perlman, 1979; Fenwick et al., 1978; Kilpatrick et al., 1980). Acetylcholine stimulated the release of both the endogenous catecholamines and preloaded ${ }^{3} \mathrm{H}-\mathrm{NE}$ in only two of the four dispersions (patients 9 and 19). In the other two cell dispersions, acetylcholine did not stimulate the release of both the preloaded ${ }^{3} \mathrm{H}-\mathrm{NE}$ and the endogenous catecholamines, although it caused the release of one or the other. The nonparallel release of the newly sequestered ${ }^{3} \mathrm{H}-\mathrm{NE}$ relative to the release of the older, endogenous stores of $\mathrm{E}$ and NE in these pheochromocytoma cells was also reported by Wilson et al. (1981) in cells from one tumor and is in contrast to their parallel release in normal bovine adrenomedullary cells (Kilpatrick et al., 1980; Trifaro and Lee, 1980). These observations suggest that a change in cateholamine storage or release pools is a common occurrence in pheochromocytoma and that this change may be a causative factor in the etiology of the disease. The elevated basal release of some of the cells was consistent with the hypothesis that elevated plasma catecholamines are associated with defective storage or catecholamine synthesis mechanisms (Manger and Gifford, 1977). However, hyper-secretion by tumors with cells that appear to have "normal" basal secretion and acetylcholine responsiveness must be explained by other, as yet undetermined, mechanisms.
The acetylcholine-stimulated release described here reflects not only activation of nicotinic (Wilson et al., 1981) and/or muscarinic (Koelle, 1970) receptors on the cells, but also the relative rate of metabolism of acetylcholine by each tumor cell culture. Acetylcholinesterase activity has been described in adrenomedullary cells (Mizobe and Livett, 1980) and rat PC12 cells (Greene and Tischler, 1982), but not in human pheochromocy. toma tissue or cells. Although acetylcholinesterase activity may have been present, we did not use an acetylcholinesterase inhibitor because of unpredictable side effects, i.e., 1) these inhibitors may stimulate muscarinic receptors (Taylor, 1980), and 2) $8 \mu \mathrm{M}$ eserine actually inhibited acetylcholine-stimulated release of catecholamines from human pheochromocytoma cells (data not shown). A time-dependent increase in acetylcholinesterase activity partially inhibited acetylcholinestimulated release in bovine adrenomedullary cells (Mizobe and Livett, 1980), and a similar phenomenon could confuse the interpretation of our data. However, it does not appear that time-dependent variations in the activity of a putative acetylcholinesterase are responsible for the different secretory patterns reported here. The cells from patients 1,9 , and 13 were of similar age $(5,5$, and 8 days respectively), while the cells from patient 18 , which were 13 days of age, had the greatest acetylcholine-stimulated release of the endogenous catecholamines (Table 2).

In summary, we have described: 1) a large variation in cell yield between tumors; 2) a large variation in cell size, within and between tumors; 3) a lack of correlation between tissue and cellular catecholamine content; 4) the kinetics of the decrease of cellular catecholamine content with time in culture and the inability of various media and serum combinations to prevent this decrease; 5) the existence of and variation in the expression of an NE uptake system; and 6) the expression of different secretory patterns among different tumor cell cultures. These studies should provide a foundation for further biochemical investigation of this tumor.

\section{ACKNOWLEDGMENTS}

We thank Mr. James A. Baker for excellent technical assistance and Ms. Linder Markham and Ms. Diane Vecellio for help in preparing this manuscript. In particular, we thank Drs. James C. Sisson and Ronald E. Holz for their encouragement and suggestions. This investigation was supported by NIH, NIAMDD grant No. AM21477.

\section{LITERATURE CITED}

Anderson, B.G., Beierwaltes, W.H., Harrison, T.S., Ansari, A.N., Buswink, A.A., and Ice, R.D. (1973) Labeled dopamine concentration in pheochromocytomas. J. Nucl. Med., 14:781-809.

Anton, A.H., and Sayre, D.F. (1962) A study of the factors affecting the aluminum oxide trihydroxy indole procedure for the analysis of catecholamines. J. Pharm. Exp. Ther., 138:360-375.

Blaschko, H., Jerome, D.W., Robb-Smith, A.H.T., Smith, A.D., and Winkler, H. (1968) Biochemical and morphologic studies on catecholamine storage in human pheochromocytoma. Clin. Sci., 34:453-465. Bottenstein, J.E., and Sato, G.H. (1979) Growth of a rat neuroblastoma cell line in serum-free supplemented medium. Proc. Nat. Acad. Sci. USA, $76(1): 514-517$.

Bottenstein, J.E., (1983) Growth requirements of neuronal cells in vitro. In: Advances in Cellular Neurobiology. S. Fedoroff and L. Hertz, eds. Academy Press, New York, Vol. 4, pp. 333-379.

Cabana, B.E., Prokesch, J.C, and Christiansen, G.S. (1964) Study on the biogenesis of catecholamines in pheochromocytoma tissue culture. Arch. Biochem. Biophys., 106:123-130. 
Costero, 1., Chevez, A.Z., Peralta, L., Monroy, E., and Ramon, R. (1965) Rhythmic cellular movements in tissue cultures of pheochromocytoma and adrenal medulla. Texas Rep. Biol. Med. 23:213-220.

De La Torre, J.C., and Surgeon, J.W. (1976) A methodological approach to rapid and sensitive monoamine histofluorescence using a modified glyoxylic acid technique: The SPG method. Histochem., 48:81-93.

Dickinson, E.S., and Slakey, L.S. (1982) Plasma derived serum as a selective agent to obtain endothelial cultures from swine aorta. In Vitro, 18: 63-70.

Eranko, O. (1976) SIF cells, chromaffin cells, granule containing cells and interneurons. In: SIF Cells, Structure and Function of the Small, Intensely Flourescent Sympathetic Cells. O. Eranko, ed. DHEW Publication No. (NIH) 76-942, pp. 1-7.

Feldman, J.M., Blalaock, J.A., Zern, R.T., and Wells, S.A., Jr. (1979) The relationship between enzyme activity and the catecholamine content and secretion of pheochromocytomas. J. Clin. Endocrinol. Metab., 49:445-451.

Feldman, J.M. (1981) Phenylethanolamine-N-methyltransferase activity determines the epinephrine concentration of pheochromocytomas. Res. Comm. Chem. Path. Pharmacol, 34:389-398.

Fenwick, E.M., Fajdiga, P.B., Howe, N.B.S., and Livett, B.G. (1978)

Functional and morphological characterization of isolated bovine adrenal medullary cells. J. Cell. Biol., 76:12-30.

Gilbert, S.F., and Migeon, B.R. (1975) D-Valine as a selective agent for normal human and rodent epithelial cells in culture. Cell, 5:11-17.

Greene, L.E., and Tischler, A.S. (1982) PC12 pheochromocytoma cultures in neurobiological research. In: Advances in Cellular Neurobiology. S. Fedoroff and L. Hertz, eds. Academic Press, New York, Vol. 3, pp. 373-414.

Hochman, J., and Perlman, R.L. (1976) Catecholamine secretion by isolated adrenal cells. Biochim. Biophys. Acta, 421:168-175.

Jaques, S., Jr., Tobes, M.C., Sisson, J.C., Baker, J.A., and Wieland, D.M. (1984) Comparison of the sodium dependency of uptake of metaiodobenzylguanidine and norepinephrine into cultured bovine adrenomedullary cells. Molec. Pharm., 26:539-546.

Kadin, M.E. and Benseh, K.G. (1971) Comparison of pheochromocytomas with ganglion cells and neuroblasts grown in vitro: An electron microscopic and histochemical study. Arch. Histol. Jpn. (Suppl), 40:61-79.

Kanerva, L., and Hervonen, A. (1976) SIF cells, short adrenergic neurons and vacuolated nerve cells of the paracervical (Frankenhauser) ganglion. In: SIF Cells, Structure and Function of the Small, Intensely Fluorescent Sympathetic Cells. O. Eranko, Ed. DHEW Publication No. (NIH) 76-942, pp. 17-34.

Kilpatrick, D.L., Ledbetter, F.H., Carson, K.A., Kirshner, A.G., Slepetis, R., and Kirshner, N. (1980) Stability of bovine adrenal medulla cells in culture. J. Neurochem., 35:679-692.

Koelle, G.B. (1970) Parasympathomimetic agents. In: The Pharmacological Basis of Therapeutics (4th Ed.). L.S. Goodman and A. Gilman, eds. Macmillan, New York, pp. 466-477.

Lamberts, S.W.J., Bruining, H.A., Alexiev, A., Van Essen, L.H., DeGreef, W.J., and Oosterom, R. (1984) "Hypotension" as presenting symptom in fatal and near-fatal pure adrenaline-secreting phaeochromocytomas. Neth. J. Med., 27:385-388.

Lang, B.T., and Perlman R.L. (1979) Catecholamine secretion by hamster adrenal cells. J. Neurochem., 32:927-933.

Manger, W.M., and Gifford, R.W. (1977) Pheochromocytoma. SpringerVerlag, New York.
Misugi, K., Misugi, N., and Newton, W.J. (1968) Fine structural study of neuroblastoma, ganglioneuroblastoma and pheochromocytoma. Arch. Path., 86:160-169.

Mizobe, F, and Livett, B.G. (1980) Production and release of acetylcholinesterase by a primary cell culture of bovine adrenal medullary chromaffin cells. J. Neurochem., 35:1469-1472.

Nishihira, T., Kasai, M., Hayashi, Y., Kimura, M., Matsumure, Y., Akaishi, T., Ishiguro, S., Kataoka, S., Watanabe, H., Miura, Y, and Haruo, S. (1980) Experimental studies on differentiation of cells originating from human neural crest tumors in vitro and in vivo. Cell Molec. Biol., 27:181-196.

Passon, P.G., and Peuler, J.D. (1973) A simplified radiometric assay for plasma norepinephrine and epinephrine. Anal. Biochem., 51:618631.

Pfragner, R., and Walser, V. (1980) Long-term culture of human pheochromocytomas. Exp. Path., 18:423-429.

Pfragner, R., Sadjak, A., and Walser, V. (1984) The effect of nerve growth factor (NGF) on the catecholamine contents of two human pheochromocytomas in tissue culture. Exp. Path., 26:21-31.

Taylor, P. (1980) Anticholinesterase agents. In: The Pharmacological Basis of Therapeutics (6th Ed.). A.G. Gilman, L.S. Goodman, and A. Gilman, eds. Macmillan, New York, pp 100-119.

Tischler, A.S., Dichter, M.A., and Biales, B. (1976) Neuronal properties of cultured human endocrine tumor cells of proposed neural crest origin. Science, 192:902-904.

Tischler, A.S., Lee, H.C., Perlman, R.L., Costopoulos, D., Slayton, V.W., and Bloom, S.R. (1984) Production of "ectopic" vasoactive intestinal peptide-like and neurotensin-like immunoreactivity in human pheochromocytoma cell cultures. J. Neuroscience, 4:1389-1404.

Tischler, A.S., Allen, J.M., Costopoulos, D., and Bloom, S.R. (1985) Increased content of neuropeptide $\mathrm{Y}$ in human pheochromocytoma cell cultures. J. Clin. Endocrinol. Metab., 61:303-305.

Trifaro, J.M., and Lee, R.W.H. (1980) Morphological characteristics and stimulus-secretion coupling in bovine adrenal chromaffin cell cultures. Neuroscience, 5:1533-1546.

Tobes, M.C., Jaques, S., Jr., Wieland, D.M., and Sisson J.C. (1985) Effect of uptake-one inhibitors on the uptake of norepinephrine and metaiodobenzylguanidine. J. Nucl. Med., 26:897-907.

Unsicker, K. (1983) Cell and tissue culture studies on the sympathoadrenal system. In: Autonomic Ganglia. Lars-Gosta Elfvin, ed. John Wiley and Sons, Ltd., New York, pp. 475-505.

Wilson, S.P., Slepetis, R., Chang, K.-J., Kirshner, N., and Viveros, H. (1981) Different secretion of opioid peptides and catecholamines from cultured cells of a human pheochromocytoma tumor. Life Sci., 29:2257-2264.

Winkler, H., and Smith, A.D. (1968) Catecholamines in pheochromocytoma. Lancet, 1:793-795.

Winkler, H., and Smith, A.D. (1972) Pheochromocytoma and other catecholamine producing tumors. In: Handbook of Experimental Pharmacology: E. Blaschko and E. Muschol, eds. Springer-Verlag, Berlin, Vol. 33, pp. 900 933.

Wrzolkowa, T., Mrozowicz, M., Lewinski, A., and Pryczkowski, J. (1975) Phaeochromocytoma. Electron microscopic study on catecholamine storage. Path. Europ., 10:179-191.

Young, M., Oger, J., Blanchard, M.H., Asdourian, H., Amos, H., and Arnason, B.G.W. (1975) Secretion of nerve growth factor by primary chick fibroblast cultures. Science, 187:361-362. 